\title{
Research and Practice on Experimental Teaching of 3D Innovation and Technology Series Courses
}

\author{
Hua Fang * \\ School of Information technology \\ Beijing Normal University, Zhuhai \\ Zhuhai, China \\ 275132997@qq.com \\ *Corresponding author
}

\author{
Mei Li \\ School of Information technology \\ Beijing Normal University, Zhuhai \\ Zhuhai, China \\ roselee2000@126.com
}

\begin{abstract}
D technology is becoming more and more popular in different fields of the society. Colleges and universities need to set up the goal of talent education from the perspective of professional orientation, and experimental teaching is the key to such a goal. However, traditional in-class teaching cannot meet the requirements of the society for the talented people with 3D innovation and 3D technology competence. Based on the "Excellent Engineers Training Program", the paper discusses experimental teaching reform from integrating curriculum, inclass teaching and out-class practice. Students' hands-on skills, development capabilities and innovative consciousness can be enhanced by establishing extracurricular practice base, engaging engineering projects and participating professional contests.
\end{abstract}

Keywords-3D innovation and technology; experimental teaching; integration

\section{INTRODUCTION}

With the development of computer technology, 3D technology is more and more popular in different fields, and the demand for talents with 3D innovation and technology is growing. In order to discuss experimental teaching, this paper takes the 3D innovation and technology series courses as an example. The objective of 3D innovation and technology series courses is to develop 3D engineering talents with the creative and designing competence and technical capacity. In 2010, the ministry of education published the "2010-2020 National medium and long-term plan for education reform and development", in which the "Excellent Engineers Training Program" (hereinafter referred as the "Excellent Program") was put forward. In recent years, a total of 194 universities participated in the program, and some achievements have been made and the common understanding has been reached: under the trend of global economic integration and the highly differentiated and highly integrated contemporary development of science and technology, the engineering education needs to develop talents with comprehensive qualities based on the idea of "Engineering with Big E", ${ }^{1}$ so that with strong hands-on ability, consciousness of creation and sense of social

\footnotetext{
${ }^{1}$ Xiaozhen Xie. "An Exploration of the Connotation and Essential Features of "Large-scale Engineering" [J]. Research in Higher Education of Engineering,2008,03:35-38.
}

responsibility, the students can adapt to the modern society. Referring to the practical experience of the "Excellent Program", the paper starts from the features of the series courses of 3D innovation and technology and discusses how to carry out the experimental teaching of 3D series courses by integrating the various resources.

\section{FEATURES OF 3D INNOVATION AND TECHNOLOGY SERIES COURSES}

\section{A. Cross Multiple Disciplines}

The "3D innovation and technology" series courses, such as "3D modeling design", "3D animation design", "3D virtual reality interaction technology" and "3D projects", are basic courses and profession-oriented courses for the major of digital media technology. One of the key features of these courses is interdisciplinary, ranging from art, communication, animation to film and television and engineering fields. The series courses are normally offered in the second and the third year, though offered as separated courses, the in-class teaching should be integrated with the knowledge of fine art and technology, so that students' comprehensive abilities can be developed. Through the study of the 3D series courses, students would not only develop the ability of modeling, lighting and material and creating 3D models and scenery quickly, but also get familiar with animation, lens editing skills and basic programming techniques, and develop engineering thinking. They would be even well prepared for the future jobs through the 3D projects.

\section{B. With Great Difficulty}

As an emerging and high value-added industry, 3D industry covers six domain areas: manufacturing design, creative digital services, cultural media, architecture design, consultation and leisure consumption. The use of 3D technology in areas above involves high-end computer application technology, and projects such as 3D virtual city, large-scale 3D game, 3D landscape design and 3D virtual online mall require technology-intensive team operation. Hence, colleges and universities not only need to develop students with 3D knowledge, hands-on skills in using software and ability in design and practical experience, but also need to pay attention to expand students' knowledge of different areas and emphasize the importance of creative designing and the ability of collaboration. The 3D series courses are rather difficult from 
the perspectives of teaching and learning and therefore, it would be crucial to build a systematic hands-on training system by considering the whole series courses.

\section{With Strong Practicability}

$3 \mathrm{D}$ series courses are closely connected with the 3D industry and with strong practicability, so a lot of short-term training courses are emerging in the market. These training courses are tailored for the company's requirements, and the trainees can go for work directly after the completion of the course, a lot of young people hence value such short-term interests. In this aspect, colleges and universities should change the way of thinking. Under the trend of continual upgrading of 3D technology and globalization, the design of 3D curriculum should not only contain technical training that the training courses offered, but also reflect the academic research in the field to enable students adapt to the social environment changes and the needs of global economic development in the future.

\section{IMPLEMENTATION OF EXPERIMENTAL TEACHING OF 3D SERIES COURSES}

Practice is the soul and fundamentals of an engineering project and is also the basic requirement for the engineering education. Referring to the "Excellent Program" and the philosophy of the "Engineering with a big E", the overall reform idea of the 3D series courses is to reform teaching contents, integrate resources, design rational experimental teaching system, carry out inquiry-learning and develop the students' overall abilities.

\section{A. Designing Rational Experimental Teaching System}

The design of teaching plan of 3D series courses is based on the idea of "comprehensive training" and "ability oriented". The main courses and other relevant courses are organized according to the cluster of subjects. Some cross-disciplinary courses, such as "Mathematics", "Program Fundamentals", "Cognitive Psychology", "Modeling Fundamentals", "Philosophy of Art" and "Communication", are offered in the first year so that students can acquire knowledge of different disciplines. The courses gradually turned to be more professional from the second year. Core courses and a large number of elective courses are offered to deepen the understanding of the field. Courses including "3D Modeling Design", "3D Animation", "3D Graphics Programming", "3D Virtual Reality Technology" and "Product Design" are offered to build a rational knowledge system. In addition, "Film and Television Production and Non-Linear Editing", "Game Design and Character Design" and some other courses are available as elective courses. At the same time, the curriculum system closely combines classroom instruction and experiments, practical modules, as shown in table 1, are included in each academic year to ensure the students' hands-on ability. "Programming" is given top priority in the first year, "3D software" in the second year and comprehensive projects on "virtual reality technology" or other digital media technology in the third year, and internship and training in company in the fourth year.

From the perspective of implementation, experimental teaching can be divided into in-class experimental teaching, campus practice, internship and graduation thesis. Experimental teaching and theoretical teaching are closely related but relatively independent in order to promote students' all-round development.

TABLE I. THEORETICAL AND PRACTICAL MODULES OF EACH ACADEMIC YEAR

\begin{tabular}{|c|l|l|}
\hline $\begin{array}{c}\text { Academic } \\
\text { Year }\end{array}$ & \multicolumn{1}{|c|}{ Theoretical Modules } & Practical Modules \\
\hline $1^{\text {st }}$ Year & $\begin{array}{l}\text { Mathematics } \backslash \text { Programming } \\
\text { Fundamentals } \backslash \text { Communica- } \\
\text { tion\Cognitive Psychology } \\
\text { and etc. }\end{array}$ & $\begin{array}{l}\text { Programming } \\
\text { Practiceln-class } \\
\text { PracticelDifferent } \\
\text { kinds of Contests }\end{array}$ \\
\hline $2^{\text {nd }}$ Year & $\begin{array}{l}\text { 3D Modeling Fundamentals } \\
\text { l3D Animation }\end{array}$ & $\begin{array}{l}\text { Skills and Practice of } \\
\text { 3D Softwares } \backslash \\
\text { In-class Practice } \backslash \\
\text { Projects }\end{array}$ \\
\hline $3^{\text {td }}$ Year & $\begin{array}{l}\text { 3D Graphics Programming } \backslash \\
\text { 3D VR Technology } \backslash \\
\text { Computer Graphics }\end{array}$ & $\begin{array}{l}\text { 3Dvirtual simulation } \\
\text { l3D Scene Roaming } \backslash \\
\text { Complex Projects }\end{array}$ \\
\hline $4^{\text {th }}$ Year & $\begin{array}{l}\text { Digital Media technology } \backslash \\
\text { Company Tailor-made } \\
\text { Training Course }\end{array}$ & $\begin{array}{l}\text { Internship } \backslash \text { Company } \\
\text { Training Graduation } \\
\text { Thesis }\end{array}$ \\
\hline
\end{tabular}

\section{B. Deepening the Reform of Classroom Teaching and Improving Experimental Teaching}

The classroom is the place where the teacher and the students communicate face-to-face and it is also the basic platform for experimental teaching. Usually, at the beginning of a specific course, the teaching objectives and the teaching contents need to be planned, the emphasis should be clarified with the demand of the $3 \mathrm{D}$ industry, the key points should be listed and the required course project should be informed.

1) Arranging knowledge taught in the class into units with the combination of the demand of the industry. Classroom is the fundamental platform to improve students' practical ability, in which the teacher guides the students entering the professional field and mastering the basic knowledge and skills. In previous $3 \mathrm{D}$ classes, priority is given to software operation, however, as the course is abstract and dull in nature, the students feel it very difficult to learn, and many students cannot keep up with the progress of classroom teaching. As a result, in-class practice cannot be completed in time and the accumulated difficult points are increased, which leads to the phenomenon of growing number of absence. Take the "3D modeling" course as an example, the course lasts for 18 weeks and 18 knowledge points are integrated into four units: modeling, material, lights and cameras, and animation technology. At the same time, hierarchical examples and practice are designed to adapt to the students with different leaning abilities. At the end of the semester, teachers would organize in-class cases and edit guidance for course experiments.

2) Providing multi-dimensional learning materials. To most of the students, 3D technology is relatively difficult and the priority of classroom instruction should therefore be given to practice. Generally speaking, an introduction about the features, application fields and the final effect of a certain technology is given at the beginning, and then the video, URL links, and experiment instructions are provided. For example, in the course of 3D Modeling, there is a part on transforming 
2D graphics to 3D models. 3Ds MAX offers a variety of basic modeling methods: extrusion and chamfering, chamfering deformation and lofting and etc. Each method is suitable for physical models with different characteristics, and sometimes integrated methods need to be used to complete a complex model. It would be difficult for the students to master all these modeling methods in class. However, after the brief overview of the knowledge points, helping students to establish the understanding of these technologies, students can select the examples that fit their levels to practice independently according to the provided learning materials. Such teaching method enable students not only grasp the in-class knowledge but also improve their learning efficiency.

3) Designing comprehensive projects and stressing the cultivation of students' innovative quality. As technologies spread faster and faster, some students are already familiar with the operation of 3D software before the commencement of the course, and some students who have strong learning ability can easily master the basic use of the 3D software. In addition, today's massive open online courses (MOOC) enable students have an access to knowledge and information, especially the learning resources about the use of software on the web. As a result, it makes it possible that students can learn by theirselves and involve in projects ahead of schedule. Therefore, comprehensive project tasks can be designed, related learning materials can be provided and inquiry-learning method can be used to encourage the students to improve their personal innovative qualities. Take the 3D Animation course as an example, comprehensive tasks including "indoor roaming animation", "product display animation" and "virtual scene travelling" can be designed. Projects evaluation criteria with the combination of the industry standard can be set up and the students can be required to complete the tasks as a team. In addition, practice can be made after class. With the convenience of the network and the mobile devices, the teacher can communicate with the students after class, answering all kinds of questions raised by the students. Such comprehensive projects would last for the whole semester and are included in the curriculum assessment. The works in the projects can also be taken to extracurricular competitions.

\section{Establishing extracurricular practice bases for improving students' practical abilities}

"Under the knowledge economy and global competition environment, the society needs talented human capital, continuous innovation of products and services. " ${ }^{2}$ Practice bases need to be developed to ensure that experimental teaching can be conducted throughout the class, and be run through the 3D series courses. The school where the author teaches has developed laboratories of all levels - Zhuhai Public Experimental Platform for Images and Graphics, ZhuHai

2 Tongwen $\mathrm{Xu}$, Yan Chen. Analysis and Inspiration on Education of Application-Oriented Talent of British Universities [J].Higher Education Exploration on Application-Oriented Talent,2013.02:31-35.
Network Platform for High-tech Zone, Electronic Innovation Laboratory and Software Testing Laboratory- to ensure the implementation of the experimental teaching. In addition, a number of professional associations, such as the Association for Electronic Fan, the Association of ACM and the Association for Digital Media Creativity, have been set up and the students can participate in the activities arranged by these extracurricular practice bases according to personal interests. As the association is open to the whole university, students of different majors can participate and such multi-disciplinary background make it a beneficial supplement in the process of experimental teaching.

3D series courses take the "Association for Digital Media Creativity" as a platform and carry out different levels of practice, from small research tasks to real projects, guiding students and teams to attend competitions of different levels and disciplines and arranging training accordingly. Through the reform of the experimental teaching, dozens of students from the major of digital media technology participate in the competitions for 3D technology and multiple project teams win awards in many domestic contests. Such reform has not only won honors and praises for the school, but also improved the level of scientific research and teaching.

In order to improve the professional competence of all the students, the school where the author teaches even requires that all the students need to complete a comprehensive project under the teachers' guidance during the whole month of July in their third year and the results of the project would be evaluated and recorded. The assessment of 3D series courses no longer relies on the final test, a flexible and effective assessment mechanism which focuses on the "process" has been established, and the students' award in professional competitions and their works from the projects also become part of the assessment indicators.

\section{Establishing extracurricular practice bases for improving students' practical abilities}

The "Excellent program" requires enterprise's participation and encourages the enterprises and the universities to develop teaching plans jointly. During the first year to the third year, considering the changes of the social demand, the lectures given by the company would be welcomed and real projects from the industry would be even introduced into the class. In 2012, the Letao-commerce platform wished to upgrade its shopping environment and created a 3D interactive virtual shopping mall, as a result, a large number of 3D model products with high quality would be needed. With the introduction of Letao project into the classroom of 3D modeling, the students are required to complete 3D models of certain products according to the enterprise's standard. With such real projects, students come to understand the modeling standards of different industries and acquire useful knowledge by practice and develop skills and engineering ability. In addition, the teaching plan of 3D series courses also reflects the enterprises' involvement, for instance, Kingsoft Ltd, one of the leaders of domestic software development enterprises, set up the "Kingsoft training camp" project and selected students would go for training in the summer vacation in the third year. 
Such training no longer teaches the students the knowledge, but develop their practical capabilities.

Furthermore, the internship would be carried out in the fourth year. Some students would go for internship in the company, while some would join orientation training program held by different enterprises to better prepared for the future employment.

By the cooperation with the industry, the students' engineering consciousness and engineering practice ability can be enhanced, and the level of teachers' project practice can also be improved.

\section{CONCLUSION}

In order to develop engineering talents that meet the requirement of "Engineering with Big E", this paper discusses the experimental teaching methods and its implementation measures from the in-class teaching practice to extracurricular practice base. Firstly, course contents need to be jointly planned and designed with the industry so that the structure of the course contents could reflects the knowledge chain and capacity requirements for the major of digital media technology. Secondly, the experimental teaching need to be designed integratedly. It not only refers to design teaching contents of the 3D innovation and technology series courses systematically, but also construct a target system which aims to develop students hands-on ability by integrating experimental teaching method, learning method, evaluation methods and all aspects of experimental teaching, and corresponding teaching models to be used according to the different parts of teaching practice to achieve good teaching effect. Thirdly, students' autonomous learning ability need to be developed. The educational concept of "student-center and developing students' autonomous learning ability" is widely accepted both at home and abroad. Engineering education advocates the continuous reform for experimental teaching from the idea of "project driven, results oriented" and develop students' autonomous learning ability and self improving ability.

The teaching effectiveness improvement for the experimental teaching of the $3 \mathrm{D}$ series course is a process of continuous efforts. To adapt to the training requirements for engineering personnel under the development trend of global economic integration, universities and college need to continually deepen the reform of experimental teaching, establish a scheme that can be adapted with the students' innovative ability training, strengthen the development of experimental teaching bases, and implement measures that fulfill the objective of innovative ability training.

\section{ACKNOWLEDGEMENT}

This paper is supported by the funds of youth backbone teachers visiting scholar project in Guangdong province of China in 2013.

\section{REFERENCES}

[1] Xiaozhen Xie. "An Exploration of the Connotation and Essential Features of "Large-scale Engineering" [J]. Research in Higher Education of Engineering,2008,03:35-38.

[2] Tongwen $\mathrm{Xu}$, Yan Chen. Analysis and Inspiration on Education of Application-Oriented Talent of British Universities [J].Higher Education Exploration on Application-Oriented Talent,2013.02:31-35.

[3] Leihua Qin, Xiaolan Wang. "Analysis of Student Factors of the Plan for Educating and Training Outstanding Engineers [J]. Research in Higher Education of Engineering,2013,02:68-71.

[4] Shandong Tu. 《TOTAL ENGINEERING EDUCATION 》[M]. East China university of science and technology press,2012.

[5] Janna Q.Anderson,Jan L.Boyles,Lee Rainie, Jingzhi Wang, Baohua Wang. The Influence of Internet on Higher Education in the Future [J]. Research in Higher Education of Engineering,2013,03:38-45.

[6] Jianping Zhao, Bing Peng, Qinglei Zhao.Research on Enhancing College Students' Occupational Adaptability in International Perspective--with the "Excellent Engineer Training Program" of the Ministry of Education as the object of the research [J].Research in Higher Education of Engineering,2013,03:101-105.

[7] Jian Lin. Analysis on the Implementation Progress of "Excellent Engineer Training Program" in Colleges and Universities (2010 2012)(1)[J]. Research in Higher Education of Engineering,2013,04:1-12.

[8] Shouwen Yu.Discussion on Several Understandings of Contemporary Engineering Education [J]. Research in Higher Education of Engineering,2013.02:1-5.

[9] Jian Lin. Quality Insurance on the Education of Excellent Engineers(2)[J]. Research in Higher Education of Engineering,2013,02:24-40.

[10] The Opinions on the Implementation of Excellent Engineer Education Program by the Ministry of Education [EB/OL]
[E http://www.moe.gov.cn/publicfiles/business/htmlfiles/moe/s3860/20110 2/115066.html. 